\title{
Fra mundtlig
}

gruppeeksamen til

løbende evaluering

med portfolio

\author{
Lone Ambjørn, lektor, Institut for Sprog og Kommunikation, Handelshøjskolen, Aarhus Universitet
}

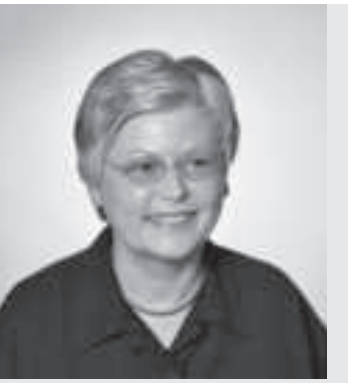

Lone Ambjørn er ansat som forsker og underviser på Handelshøjskolen, Aarhus Universitet, Institut for Sprog og Erhvervskommunikation. Siden maj 2007 har hun forskningsmæssigt været tilknyttet Center for Undervisningsudvikling ved Humaniora og Teologi, Aarhus Universitet. Hendes primære forskningsområder er sprogdidaktik, e-læring og talesprogsdiskurs. Foruden forskning og spanskundervisning beskæftiger hun sig med vejledning inden for adjunktpædagogikum

\section{Reviewet artikel}

Hensigten med denne artikel er at prosentere og argumentere for en didaktisk model, som forfatteren har udviklet på baggrund af indforelse af lobende evaluering med portfolio som en alternativ proveform til mundtlig gruppeeksamen. Modellen, der tager afseet $i$ en fremmedsproglig laringskontekst, belyses og diskuteres ud fra flo. udvalgte aspekter, som også skonnes at vere af interesse for andre fagområder: gruppevejledning $i$ et differentieret perspektiv, laringsjournalen som samarbejdsverkstoj, integreret e-laering samt medansvar for egen leering.

\section{Samtalefærdighed og mundtlig gruppeeksamen}

Afskaffelsen af mundtlig gruppeeksamen har for nogle fags vedkommende reduceret muligheden for at få moderne og tidssvarende principper for undervisning, $1 \mathfrak{l}$ ring og evaluering til at gå op i en højere enhed og dermed opnå de tilsigtede læringsmål for de berørte fag (Biggs, 2003). Hensigten med denne artikel er at præsentere og argumentere for en didaktisk model, som forfatteren har udviklet på baggrund af indførelse af lobende evaluering med portfolio ${ }^{1}$ som en alternativ prøveform til mundtlig gruppeeksamen.

Faget 'Spansk kommunikation' på BA-studiet i spansk på Handelshøjskolen, Aarhus Universitet, er blandt de berørte af afskaffelsen af mundtlig gruppeeksamen. Jeg indleder nedenfor med en beskrivelse af faget for på denne baggrund efterfølgende at argumentere for det oprindelige valg af en mundtlig gruppeeksamensform.

\section{Samtalefordighed}

Faget 'Spansk kommunikation', der udbydes på spanskstudiets 1.-3. semester, tager sigte på udvikling af de studerendes samtalefærdighed. Faget bygger på et kognitivt og konstruktivistisk læringssyn, hvor der arbejdes ud fra sproglig viden og bevidsthed, og hvor den lærende er hovedaktør i egen læringsproces. Det bagvedliggende sprogsyn er funktionelt med fokus på såvel sprogform som sprogbrug.

Ved samtalefardighed forstås her evnen til at deltage $i$ to- eller flervejskommunikation, hvor fordelingen af taleretten administreres selvstændigt af parterne, der skiftes til at have ordet og dermed rollen som afsender og modtager. Samtalen baseres på et samarbejde de deltagende parter imellem om at kommunikere på en meningsfuld måde og opbygge en fælles kohærent interaktion. Blandt de sproglige kompetencemål figurerer en række samtaleteknikker og specifikke spanske adfærdsnormer, som det imidlertid falder uden for sigtet med denne artikel at komme nærmere ind på.

Disciplinen, der er blevet til på basis af forskning inden for interaktiv talesprogsdiskurs samt sprogdidaktik, er udviklet med det formål at sætte den studerende i 
stand til at samtale naturligt og uformelt med indfødte sprogbrugere og deltage i diskussioner om generelle samfundsmæssige problemstillinger. Endvidere vil den studerende $i$ en efterfølgende jobfunktion i erhvervslivet kunne deltage i den løbende mundtlige kontakt imellem danske virksomheder og deres spansktalende handelspartnere, herunder planlægge og deltage i kundemøder.

Det primære udgangspunkt for samtaletræningen, der foregår i mindre grupper, er frie interaktive opgavetyper. Disse aktiviteter involverer udveksling of informationer vedr. personrelaterede og almene emner samt udveksling af meninger omkring både generelle og aktuelle problemstillinger i de respektive samfund.

\section{Mundtlig gruppeeksamen i samtalefardighed}

I det følgende skal jeg kort redegøre for den oprindelige mundtlige gruppeeksamen i samtalefærdighed. Med udgangspunkt heri argumenterer jeg i næste afsnit for valget af den alternative eksamensform, 'løbende evaluering med portfolio'.

Fagets mundtlige gruppeeksamen var udviklet med henblik på at sikre overensstemmelse imellem undervisningsform og eksamensform, således at eksamensformen og evalueringskriterierne testede og honorerede undervisningens mål. Hermed er jeg inde på såkaldt washback. Termen washback refererer til den indflydelse, som en prøveform kan have på undervisningsform og læringsproces. Med reference til Weir (1990), Alderson and Wall (1993) og Alderson (2004), beskriver Taylor (2005, s. 154) begrebets positive og negative side i en fremmedsproglig læringskontekst således:

"Negative washback is said to occur when a test's content or format is based on a narrow definition of language ability, and so constrains the teaching/ learning context. [...] Positive washback is said to result when a testing procedure encourages 'good' teaching practice."

I en mundtlig gruppeeksamen, der evaluerer en bred vifte af de fremmedsproglige kompetencer, der tilsammen udgør samtalefærdighed, har de studerende ingen mulighed for at øve hverken positiv eller negativ indflydelse på hinandens karakterer. Evalueringen af samtalefærdigheden er i sagens natur individuel. Det er den enkeltes fremmedsproglige færdighed i samtaleteknik, samt evne til at indgå $\mathrm{i}$ et konversationelt samarbejde med flere partnere om opbyggelsen af en dialog, der er i fokus. Deltagerne i samtalen er afhængige af hinandens tilstedeværelse og medspil, men det er den enkeltes måde at udføre rollen på i form og indhold, der bedømmes. Gruppeprøveformen med muligheden af samarbejde og samspil flere aktører imellem var helt uomgængelig, hvis opfyldelsen af de tilsigtede mål med faget skulle kunne dokumenteres. Dette til trods lykkedes det ikke at komme igennem med en dispensation fra reglen om 'kun én eksaminand ved eksamensbordet'.

\section{Løbende evaluering med portfolio og tilstedeværelsespligt}

Med henblik på fortsat at sikre en positiv washbackeffekt var det alfa og omega, at evalueringen af samtalefærdigheden fortsat kunne foregå i mindre grupper i samme symmetriske rollekonstellationer som i træningssituationen og uden fremprovokation af en kunstig kommunikativ adfærd, som eksaminators samtale med en eksaminand uvægerligt ville afstedkomme. Selv $\mathrm{om}$ det ganske vist fra ministeriel side blev påpeget, at afskaffelse af mundtlig gruppeeksamen ikke betød afskaffelse af gruppearbejde, forholder det sig således, at mange studerende i min sfære arbejder med relativt kortsigtede eksamensmål for øje. Den intensive selvstændige gruppetræning i samtalefærdighed, der læringsmæssigt er uomtvistelig i faget 'Spansk kommunikation', ville der med afskaffelsen af gruppeeksamen ikke realistisk set kunne skabes nævneværdig motivation for.

På denne baggrund forekom prøveformen lobende evaluering umiddelbart at være det mest anvendelige alternativ. Jeg opfatter denne form som en procesorienteret evalueringsform, hvor der lægges vægt på at evaluere en løbende udvikling snarere end en række enkeltstående handlinger og/eller produkter. Dette kan på sin side understøtte den sproglige læringsproces, der $i$ sidste ende skal føre til samtalekompetence. Imidlertid kunne denne prøveform ikke i sig selv løse gruppeproblematikken, da den løbende evaluering også skal imødekomme kravet om 'kun én eksaminand ved eksamensbordet'. Men ved til denne form at føje individuel portfolio som dokumentation for den enkeltes arbejde med egen læringsproces og dermed den individuelle vej til målet, kunne den formelle del af problemet løses. Dette er logisk begrundet i, at en studerende ikke på tilfredsstillende vis vil være $i$ stand til at beskrive og evaluere en læringsproces bag et produkt uden reelt at have gennemgået processen.

Portfolio er i eksamensbeskrivelsen defineret som "en systematisk samling af produkter, der løbende udarbejdes af den studerende«. Den samlede portfolio dokumenterer den individuelle læringsproces og sproglige udvikling, som den studerende har gennemløbet med henblik på at opfylde de tilsigtede målsætninger for faget. Der opereres med den private arbejdsportfolio forstået som en elektronisk mappe, hvori den studerende løbende indlægger diverse produkter, samt med eksamensportfolioen forstået som en systematisk samling af til formålet udvalgte eksempler på løbende udarbejdede produkter. Disse produkter består af læringsjournaler og e-læringsopgaver (jf. nedenstående afsnit). I fagets prøvebeskrivelse stilles der specifikke krav om antallet af produkter, der udgør en portfolio. Mere relevant end 
kvantiteten er imidlertid, at det er den studerende selv, der ud fra kvalitative kriterier udvælger de produkter, der skal indgå i bedømmelsen. Udvælgelsen underbygges endvidere af en mindre skriftlig begrundelse fra den studerendes side.

Til 'løbende evaluering med portfolio' kan der knytte sig en tilstedeværelsespligt på $75 \%$, der i så fald er en forudsætning for, at den studerende kan aflevere en portfolio til endelig bedømmelse (jf. slutnote 1). Denne mulighed giver anledning til forskellige overvejelser. Set $i$ et generelt perspektiv, er problemstillingen ifm. tilstedeværelsespligt for det første den anførte procentdel, den studerende skal være til stede i undervisningen. Procentdelen opfattes fejlagtigt af nogle studerende som det antal timer, det er nødvendigt at være til stede for at kunne bestå faget, medens man kan udeblive fra de sidste $25 \%$ uden læringsmæssige konsekvenser. For det andet må man sætte spørgsmålstegn ved, hvor meget tilstedeværelse i betydningen 'afkrydsning' og 'fysisk fremmøde' er værd læringsmæssigt, hvis ikke der knyttes en eller anden form for aktivt bidrag til tilstedeværelsen (Andersen, 2005, s. 39). For det tredje er der, efter de studerendes eget udsagn, fag, der er tilrettelagt på en sådan måde, at et obligatorisk fremmøde til timerne er overflødigt for at kunne bestå faget, og de studerende derfor kunne have brugt tiden mere konstruktivt på selvstudier eller andet studiearbejde.

Nogle studerende opfatter tilstedeværelsespligten som en hjælpeforanstaltning $i$ erkendelse af, at de, specielt i de første studieår, ikke har selvdisciplin nok til at deltage i undervisningen på frivillighedens basis. Andre studerende synes, at det forekommer unødvendigt formynderisk, ikke mindst på en højere læreanstalt. Ikke desto mindre har jeg vurderet, at tilstedeværelsespligten specielt $\mathrm{i}$ det introducerende studieår har en udmærket støttefunktion i fag, der ikke tillader de studerende at selvstudere. Dog har jeg til faget 'Spansk kommunikation' valgt at omdefinere begrebet til at omfatte fire fora: det fysiske holdundervisningsrum, det fysiske gruppetræningsrum, det fysiske gruppevejledningsrum og det elektroniske e-læringsrum. Dermed bliver definitionen af tilstedevcerelse langt bredere, mere aktiverende og fleksibelt og levner ingen mulighed for blot 'at sidde den af'.

\section{Didaktiske følgevirkninger af eksamensomlægningen}

Ændringen i prøveformen har logisk afstedkommet diverse ændringer i fagets undervisningsform og læringsmål. I de følgende afsnit vil jeg belyse og diskutere tre udvalgte områder, som den nye eksamensform mest markant har øvet indflydelse på:

- vejledning på basis af læringsjournaler

- udvidet integration af netværksstøttet e-læring

- udvikling af medansvar for egen læring

\section{Vejledning på basis af laringsjournaler}

I min optik fordrer den løbende evaluering en løbende vejledning, hvis samarbejdet om og medansvaret for den enkelte studerendes læringsproces ikke skal fremstå som tomme floskler. Vejledningen er endvidere den optimale måde, hvorpå man som underviser/vejleder kan hjælpe både gruppen og dens enkelte medlemmer til at nå det tilsigtede læringsudbytte i et differentieret perspektiv. Grundlaget for den løbende vejledning er en interaktiv elektronisk læringsjournal, som er udviklet specifikt med fagets egen didaktik for øje. Jeg skal i det følgende redegøre for de grundlæggende principper bag dens form.

Selve begrebet laringsjournal har jeg hentet fra Moon (2002), medens jeg i den grundlæggende forståelse heraf lægger mig tæet op ad det kognitive portfoliobegreb hos Dysthe (2002). I egen sammenhæng definerer jeg læringsjournalen som et samarbejdsværktøj, som samtalegruppen, dens enkelte medlemmer samt vejlederen anvender til planlægning af, refleksion over og evaluering af læringsprocessen inden for et givet tidsrum. $^{2}$

Den elektroniske læringsjournal er interaktiv og opbygges igennem dialog 1) gruppemedlemmerne indbyrdes, imellem 2) vejlederen og gruppen samt imellem 3) vejlederen og det enkelte gruppemedlem (den individuelle studerende). Journalens konkrete udformning er en skabelon, der udfyldes. Den tilpasses fra semester til semester den indbyggede læringsmæssige progression i faget. Journalen består af en fælles gruppedel og en individuel del. Gruppedelen udgør en part af samarbejdsgrundlaget for den løbende gruppevejledning, ${ }^{3}$ medens den individuelle del er udgangspunktet for løbende individuel vejledning, løbende individuel evaluering samt afsluttende individuel portfolioevaluering.

Den individuelle journal fokuserer på opstillede kompetencemål inden for sproglig læring, generel læring og e-læring. Hvad angår den sproglige læringskompetence, opstiller den studerende i samarbejde med vejleder egne læringsmål samt reflekterer over og evaluerer opfyldelsen af disse mål. Inden for den generelle læringskompetence fokuseres på omstillingsparathed og -evne samt udvikling af medansvar for egen læringsproces og samarbejdsevne. Og endelig i journalens individuelle del med fokus på e-læringskompetence vurderer den studerende egen forståelse og praktiske anvendelse af principperne i e-læringsformen samt arbejde med og udbytte af elektronisk opgaveløsning (jf. nedenstående afsnit).

I forbindelse med de individuelle læringsjournaler, der kan indgå i eksamensportfolioen, skal den studerende dokumentere sin evne til at formulere og evaluere egne læringsmål. Der lægges i bedømmelsen vægt på faktorer som konstruktiv selvkritik, refleksion, forslag til fremme af egen læringsproces og til problemløsninger. Der lægges endvidere vægt på 
den studerendes evne til at formulere sig i et behørigt læringsmæssigt metasprog, som introduceres i kursets første semester og løbende anvendes i faget. Sammenfattende kan man sige, at både journalernes tilblivelse og den efterfølgende udvælgelse og begrundelse er processer, der medvirker til at højne den studerendes metakognitive bevidsthed, hvilket på sin side fremmer medansvarlighed og selvstændighed.

I det heterogene læringsrum tilpasses undervisningens niveau, indhold og form ofte en standardiseret forløbsmodel, der formodes at være i overensstemmelse med den 'typiske' studerendes færdigheder, behov og interesser. Sådanne one-size-fits-all modeller forudsætter, at de 'atypiske' studerende tilpasser sig normen (Tomlinson, 2000). Den løbende vejledning på basis af læringsjournaler, derimod, kan skabe et højt potentiale for undervisningsdifferentiering, hvis man møder den enkelte studerende der, hvor han/hun befinder sig i den læringsmæssige udvikling, og tilpasser et givet forløb den enkeltes forudsætninger.

Selv om man indledningsvist bevidstgør de studerende om de overordnede formål med vejledning på basis af læringsjournaler, møder metoden imidlertid en vis skepsis i starten af forløbet. Det overordnede problem er, at den studerende opfatter journal og vejledning som foranstaltninger, der skal kontrollere den enkeltes arbejdsindsats i faget. Dette medfører, at de første journaler generelt udfyldes med et minimum af information og refleksion, der kun vanskeligt kan anvendes konstruktivt i vejledningsøjemed. Derfor er det en forudsætning for udbyttet af arbejdet med læringsjournalerne, at vejleder i den indledende fase iværksætter en bevidstgørende samarbejdsproces, der fremmer den studerendes forståelse af fremgangsmåden gennem praktisk anvendelse af journalen med løbende vejledende kommentarer, indtil de intenderede mål er nået.

\section{Udvidet integration af netvarksstøttet e-laring}

Siden 2004 har jeg arbejdet med integration af asynkron (tidsforskudt) netværksstøttet e-læring i faget via platformen CampusNet. I reglerne for den alternative prøveform (jf. slutnote 1) er der ikke krav om anvendelse af denne læringsform, men jeg har valgt den til mit fag med det formål at højne differentieringsaspektet $\mathrm{i}$ undervisningen samt opnå en bedre læringsmæssig udnyttelse af den afstukne undervisningstidsramme. E-læringsdelen udgør efter prøveomlægningen en del af bedømmelsesgrundlaget $i$ faget.

Integration af netværksstøttet e-læring vil tage sig forskelligt ud og have forskellige læringsmæssige formål afhængigt af fag(område). I det konkrete tilfælde har jeg henlagt arbejdet med forskellige former for forberedende sproglige aktiviteter til det elektroniske læringsrum for derved i det fysiske rum at skabe mere tid til aktiviteter, der kræver fysisk fremmøde, specielt samtaletræning i grupper og vejledning. De anvendte e-læringsopgaver (herefter: e-opgaver) i faget fokuserer på diverse sproglige samtalefænomener, som langt den overvejende del af de studerende ikke besidder et forhåndskendskab til ved studiestart, og som de generelt har ret svært ved at fă integreret $i$ deres samtaler. Endnu en fordel ved e-læringsdelen i faget er derfor, at den studerende kan arbejde med sproglige analyser, fortolkninger og kreativitetskrævende aktiviteter i eget tempo og med bedre tid til refleksion over fx forskellige løsningsforslag, egne og andres fejl samt deres årsager.

Alle de løsnings- og efterbearbejdningsforslag, de studerende i samarbejde fremkommer med til e-opgaverne, ville det være umuligt at fastholde i det fysiske rum. Dette er begrundet i, at det at tale og lytte, som man gør i det fysiske rum, er mere kognitivt belastende end at læse og skrive, som man gør i e-læringsrummet. ${ }^{4}$ Der er endvidere mange distraherende faktorer $i$ et klasseværelse, og den enkeltes opmærksomhedskurve er, som bekendt, svingende. For mange værdifulde input går tabt. Dertil kommer, at e-læringsplatformens lagringsmuligheder gør, at man remedialt kan genlæse tidligere opgaveløsninger og efterbearbejdning heraf og dermed på et senere stadium opnå en større læringsmæssig værdi end i starten af forløbet. Informationerne er tilgængelige, så længe der er brug for dem, og der kan løbende henvises og stilles spørgsmål til dem. Desuden har undervisning og læring fạet et bedre flow over tid, idet e-læringsdelen jo foregår imellem de skemasatte timer og dermed betoner og bevidstgør de studerende om læringens processuelle karakter (Ambjørn, 2006).

Den studerende skal til grund for den omtalte kvalitative udvælgelse af e-opgaverne til eksamensportfolioen lægge en dokumentation for dels sine sproglige kompetencer, dels sin samarbejdsevne ifm. løsning og efterbearbejdning af aktiviteterne i det elektroniske rum. En udvælgelse til portfolioen kan derfor med fordel baseres på så bred en vifte som muligt af de forskellige aktive deltagelsesmuligheder i det elektroniske debatforum.

En skriftlig rundspørge blandt de spanskstuderende årgang 2007 har vist, at kun meget fă har forhåndskendskab til egl. netværksstøttet e-læring. Størsteparten af de studerende er vant til at bruge en elektronisk platform til at hente information og materialer, men en anvendelse i decideret læringsøjemed er stort set ukendt. Derfor har en bevidstgørelse om fremgangsmåde, formål og læringspotentiale samt en 'learning by doing' proces været en forudsætning for, at denne del af undervisningen har kunnet gennemføres med et positivt læringsudbytte.

Blok (2005) pointerer betydningen af fra starten af et e-læringsforløb at opstille klare mål, formål og udmeldinger om, hvilke forventninger og krav der stilles. ${ }^{5}$ Som endnu et led i optimering af processen anbefaler Blok, baseret på Salmon (2002), at lægge ud med en række såkaldte E-tiviteter, hvorigennem deltagerne kan 
danne deres egne erfaringer på området samt motiveres til at deltage aktivt i e-læringsprocessen og hermed højne forståelsen af formålet. Denne anbefaling har jeg for første gang ført ud i livet med de studerende årgang 2007 ud fra en formodning om, at sådanne introducerende aktiviteter ville bidrage til mindskelse af den skepsis og modvilje over for e-læring, som nogle studerende nærer og har svært ved at overvinde. Resultatet af denne afprøvning har været positiv på den måde, at flere studerende end fra foregående årgange hurtigere og mindre problemfrit er kommet i gang med denne del af faget.

Kravet om, at et givet antal e-opgaver skal lægges i eksamensportfolioen som dokumentation for den studerendes sproglige udvikling samt evne til at samarbejde med andre om opgaveløsning, medførte i starten af forløbet en uhensigtsmæssig adfærd i det elektroniske rum. Ganske vist betød kravet - ikke overraskende en markant kvantitativ højnelse af aktive indlæg i det såkaldte Debatforum, men på samme tid dalede samarbejdskvaliteten tilsvarende markant. I stedet for at forholde sig til indholdet i de indlæg, der allerede lå i en opgavetråd, valgte et større antal studerende blot at indlægge egne løsningsforslag, hvilket medførte en større mængde enslydende besvarelser uden indbyrdes sammenhæng. Denne adfærd fik til gengæld det positive udfald, at de studerende selv fandt det formålsløst at læse mange enslydende indlæg i det elektroniske rum og derfor pålagde sig selv og hinanden kun at supplere de fremkomne indlæg og i højere grad diskutere opgaveløsningernes brugbarhed. Men dette eksempel er et blandt flere på, at de studerende ofte er meget produktorienterede i deres læringsmæssige tilgang, og at en forudsætning for at drage positive fordele af den netværksstøttede e-læring er en bevidstgørelse af de studerende om denne forms potentialer i et mere procesorienteret samarbejdsperspektiv.

\section{Udvikling af medansvar for egen laring}

Den største udfordring, jeg gennemgående har oplevet ifm. fagets didaktiske tilgang, har været at få de studerende til at omstille sig fra mere traditionelle og lærerstyrede metoder til den konstruktivistiske model og konceptet medansvar for egen laring. Hos Thanasoulas (2000), der belyser forskellige forudsætninger for autonomi i en fremmedsproglig læringskontekst, skildres problemstillingen meget nøjagtigt:

"[...] if learners labour under the misconception that learning is successful only within the context of the 'traditional classroom', where the teacher directs, instructs, and manages the learning activity, and students must follow in the teacher's footsteps, they are likely to be impervious or resistant to learnercentred strategies aiming at autonomy, and success is likely to be undermined." (ibid, s. 12).
Af de studerendes læringsjournaler fremgår det med al ønskelig tydelighed, at det ved studieopstart er ukendt for langt størsteparten af dem, at underviseren i sagens natur ikke kan være den hovedansvarlige for den studerendes læringsproces. Ligeledes erkender mange, at deres holdning til sproglig læring samt manglende omstillingsparathed og -evne blokerer for, at de i den indledende fase făr det intenderede udbytte af faget. Ifm. omlægningen af fagets prøveform valgte jeg derfor at få ekspliciteret i fag- og prøvebeskrivelsen, at de studerende, med henblik på at opfylde de sproglige kompetencemål, skal oparbejde viden om sproglige læringsprocesser og -værktøjer, evne til at formulere og evaluere egne læringsmål samt evne til at tage et medansvar for egen læring. Af samme årsag indgår nu, som en central del af faget, udvikling af de studerendes metakognitive, kognitive og socio-affektive bevidsthed (Oxford, 1990). De studerende gives således indsigt i bl.a. generelle og færdighedsspecifikke aspekter af sproglig læring; de tilsigtede læringsmål med givne aktiviteter; selvevaluering; metoder og indfaldsvinkler til at nå givne læringsmål; selektivitets- og differentieringsmuligheder i læringsprocessen; principperne i elæring; samarbejdsstrategier i det fysiske og elektroniske læringsrum; personlig motivation.

En klar forudsætning for, at denne bevidstgørelse har en læringsmæssig effekt, er imidlertid, at der løbende vejledes i, hvordan teorien kan finde sin praktiske anvendelse. Ikke desto mindre må man som underviser og vejleder være forberedt på, at en del af de studerende er ret forbeholdne over for værdien heraf, indtil den tilsigtede virkning begynder at manifestere sig som positive (del)resultater i læringsprocessen.

\section{Afrunding}

Formålet med denne artikel har været at illustrere og argumentere for en måde, hvorpå den afskaffede mundtlige gruppeeksamen kan erstattes af løbende evaluering i kombination med løbende procesvejledning og afslutningsvist aflevering af en portfolio indeholdende produkter, der dokumenterer den enkelte studerendes tilgang til egen læringsproces i det pågældende fag. Jeg har fokuseret på udvalgte aspekter af en didaktisk model, som kan være af interesse ikke alene $\mathrm{i}$ fremmedsprogsundervisningen, men også inden for andre fagområder, hvor afskaffelse af den mundtlige evalueringsform har fået en uheldig indvirken på undervisningens planlægning, gennemførelse og læringsudbytte.

Opgaven for den kommende tid bliver fortsat at afprøve modellen på flere hold i sammenhængende forløb og kritisk at observere dens indvirken på udviklingen af de studerendes samtalefærdighed. På implementeringens aktuelle stadium har jeg ikke observeret egentlige ulemper ved tilgangen, men jeg har i artiklen peget på en række forudsætninger for dens anvendelig- 
hed og læringspotentiale. Sammenfattende skønner jeg, at 'løbende evaluering med portfolio' er et anvendeligt alternativ til mundtlig gruppeeksamen, når intentionen er at opretholde en positiv washback-effekt på undervisningsform og læringsproces. Fingerpeg i den retning har jeg fra læringsjournalerne, som de studerende også uopfordret anvender til løbende evaluering af faget, hvortil kommer et positivt resultat af en såkaldt midtvejsevaluering af de studerendes kompetencer $i$ faget ved slutningen af forårssemestret ' 07 .

Endelig er der, i stedet for den tidligere produktorienterede summative evaluering, nu opnået en højere grad af en procesorienteret formativ evalueringsform, som er i bedre overensstemmelse med fagets overordnede tilgang. Den nye prøveform er en integreret del af selve læringsprocessen, hvilket medfører et bredere bedømmelsesgrundlag og en højere grad af validitet $i$ bedømmelsen.

\section{Referencer}

Alderson, C. \& Wall, D. (1993). Does washback exist? Applied Linguistics, 14, 115-129.

Alderson, C. (2004). Foreword. I: L. Cheng, Y. Watanabe, \& A. Curtis (eds.).Washback in language testing: Research contexts and methods. London: Lawrence Erlbaum.

Ambjørn, L. (2006). Differentiering og kreativitet i det elektroniske asynkrone læringsrum. Sprogforum, 38, 37-44.

Andersen, H. L. (2005). Eksamensformer:Valg med konsekvenser. Aarhus Universitet: Arbejdspapirer fra Center for Undervisningsudvikling 2005-1.

Biggs, J. (2003). Aligning teaching and assessing to course objectives. Teaching and learning in higher education: New trends and innovation, University of Aveiro, 13.-17. april, 1-9.

Blok, R. (2005). Undervisningen i netvarket. - E-loring, E-struktion og E-tiviteter. Odense: Syddansk Universitetsforlag.

Clark, R., Nguyen, F., \& Sweller, J. (2006). Efficiency in learning. Evidencebased guidelines to manage cognitive load. San Francisco: Pfeiffer

Dysthe, O. (2002). Teoretisk perspektiv på mappevurdering. Nasjonalt nettsted for IKT i underviserutdanning (LUNA).
Moon, J. (1999/2002). Learning journals. - A handbook for academics, students and professional development. London: Kogan Page.

Oxford, R. L. (1990). Language learning strategies. - What every teacher should know. Boston, Massachusetts: Heinle \& Heinle Publishers.

Salmon, G. (2002). E-tivities. London: Kogan Page.

Taylor, L. (2005). Washback and impact. ELT Journal 59/2, 154-155.

Thanasoulas. (2000). What is learner autonomy and how can it be fostered? The Internet TESL Journal, 1-12.

Tomlinson, C. A. (2000). How to differentiate instruction. Reconcilable differences? Educational Leadership, 58/1, 1-7.

Weir, C. J. (1990). Understanding and developing language tests. London: Prentice Hall.

\section{Noter}

1 Regler for prøveformen Lobende evaluering udarbejdet af BA- og Kandidatstudienævnet, ISEK, ASB, Aarhus Universitet:

En eller flere skriftlige opgaver og/eller et eller flere individuelle mundtlige oplæg. De skriftlige opgaver kan udarbejdes individuelt eller i grupper. Hvis opgaverne er udfærdiget i grupper, skal de fremstå som et hele, men dog således, at den enkelte deltagers bidrag tydeligt fremgår. Opgaverne kan bedømmes løbende eller afleveres til samlet bedømmelse i en individuel portfolio ved kursets afslutning.

De mundtlige oplæg skal kunne dokumenteres i form af skriftligt materiale (f.eks. synopsis, handouts, læringsjournaler o. lign. eller underviserens notater). Bemærk at der som følge af reglerne om gruppeprøver ikke kan holdes mundtlige oplæg på basis af skriftlige gruppebesvarelser. Aktiviteterne kan kombineres med krav om $75 \%$ tilstedeværelse ved undervisningen.

2 Dette tidsrum er typisk på 2-3 uger. Der udarbejdes gennemsnitligt tre journaler pr. semester.

3 Hver samtalegruppe modtager ca. en halv times vejledning hver anden uge $i$ hvert af fagets tre semestre.

4 Jf. teorien om kognitiv belastning (Clark, Nguyen, \& Sweller, 2006).

5 Blok (2005) tager ganske vist udgangspunkt i ren e-læring uden fysisk fremmøde, men samme bevidstgørende hjælpeforanstaltninger er lige så anbefalelsesværdige i situationer med integreret e-læring. 